\title{
Renovation of Paris museum leaves collection in disarray
}

Paris. The reopening later this year of the Grande Galerie of the Natural History Museum in Paris after almost 30 years should greatly contribute to the public's understanding of evolutionary biology. But a better showcase for some of the Galerie's 76 million specimens is a mixed blessing to researchers angry about the government's unwillingness to repair extensive damage to the museum's scientific collections from repeated flooding of an underground storage facility.

An architectural contemporary of the Eiffel Tower, the Grande Galerie was opened in 1889 to store and exhibit the museum's burgeoning collections. It was closed to the public in 1965 after falling into disrepair. (Its 600,000 litres of alcohol in specimen jars were also a fire risk.) In 1988, President François Mitterrand made an impromptu visit and, shocked by its state of ruin, came to the rescue by taking FF400 million(US\$80 million) from the government's prestigeprojects fund. Five years later, the restoration is nearly done.

The large sum being spent on the Galerie contrasts with the emergency FF1 million allocated for restoring the collections, which have deteriorated more during the past seven years than in the previous three centuries. In 1986, the collections were transferred from the Galerie into an enormous underground "Zoothéque", built at a cost of FF45 million. But poor design (at a depth of 13 metres the Zoothéque is below the water table) and faulty construction have exposed the collection to a series of floods.

In addition to the need for immediate preservation, there is also concern over the long-term fate of the collections. The museum is repairing the Zootheque and suing the contractors, but staff would prefer a new facility to be built above ground. It is thought that an underground site was chosen to avoid the prohibition against increasing the amount of laboratory space in central Paris, part of an effort to decentralize research (see Nature 356; 373, 1992).

André Doumenc, a biology professor who studies marine invertebrates and molluscs, says that his recent request to attach an above-ground storage facility to the Grande Galerie was rejected because of political pressure to finish construction in time for the museum's bicentenary later this year. Researchers are concerned that the collections will be scattered throughout the provinces if no permanent home exists for them.

The new Galerie is in itself controversial, with many of the museum's senior academics criticizing it as a EuroDisney of evolution. But Michel van Praët, a marine invertebrate zoologist who heads the committee of scientists, architects and media experts responsible for the design of the new Galerie, says that it would be disastrous to give scientists complete control of public exhibitions because "they neither understand nor like the roles of the architects and media".

Van Praët has tried to make the museum more accessible; the results are imaginative exhibitions of the sweep of biodiversity, the mechanism of evolution and the effect of humanity on his planet, not to mention laser shows and sound effects.

Moreover, some of the criticism of the new Galerie can be traced to unhappiness over administrative reforms that have reduced the power of senior scientists. Last November, for example, a century-old system by which the museum's 26 professors controlled the museum's budget of FF140 million and 1,400 staff was abolished. In its place is a system more like that of a university, including a larger governing council and the replacement of life chairs by four-year appointments, renewable once.

Doumenc concedes that reform was overdue, but he is concerned that short-term appointments and separation of the museum's exhibition and research functions will dilute the commitment to doing science at one site.

Declan Butler

\section{IMAGE UNAVAILABLE FOR COPYRIGHT REASONS}

This 3.5-million-year-old Australopithecus afarensis couple is part of the new Hall of Human Biology and Evolution opening on 23 April at the American Museum of Natural History in New York. A successor to the popular Hall of the Biology of Man, which closed in 1984 after 25 years, the new permanent exhibition explores evolution, biology and anatomy as well as the origins of creativity, architecture and culture. The figures are part of a life-size diorama created on the basis of bipedal footprints discovered in Tanzania.

\section{Syria prodded to end human rights abuses}

Washington. The US National Academy of Sciences has issued a report on human rights violations in Syria as part of a campaign to convince the Syrian government that restoring human rights is a precondition to scientific cooperation.

Twelve years in the making, a report by the academy's Committee on Human Rights documents the cases of 287 scientists, engineers and health professionals who have been detained or imprisoned without charge or trial in the past decade. Forty-nine appear to have been released since 1991 as part of an amnesty which may have freed 3,500 people, almost half of those believed to be held illegally. But the report warns that many of those released have been unable to resume their careers and that new or repeat arrests are common.

The academy last month presented the report to the Syrian ambassador in Washington, Walid Al-Moualem, and asked Syria to abide by the international human rights treaties it has signed, to release a list of detained and incarcerated scientists and to restore the autonomy of scientific and professional organizations.

An academy delegation was invited to Syria for a science meeting in November 1992, but Syrian President Hafez al-Assad refused to allow its members to meet government officials to discuss human rights issues. In response, the academy withdrew its participation. Nevertheless, the committee believes that the collapse of the Soviet Union has deprived Syria of its chief ally and benefactor.

Jenna Roberts
The renovation of the Grand Galerie, show
work began in 1991, is almost complete. 